Article

\title{
Explaining Variation in Abundance and Species Diversity of Avian Cestodes in Brine Shrimps in the Salar de Atacama and Other Chilean Wetlands
}

\author{
Stella Redón ${ }^{1,2,3}$, Gonzalo Gajardo ${ }^{1}(\mathbb{D})$, Gergana P. Vasileva ${ }^{4}\left(\mathbb{D}\right.$, Marta I. Sánchez ${ }^{3}$ and Andy J. Green ${ }^{2, *(\mathbb{D})}$ \\ 1 Laboratory of Genetics, Aquaculture \& Biodiversity, Universidad de Los Lagos, Avda. Fuchslocher 1305, \\ Osorno 5290000, Chile; mredon@us.es (S.R.); ggajardo@ulagos.cl (G.G.) \\ 2 Department of Wetland Ecology, Estación Biológica de Doñana, Américo Vespucio 26, 41092 Seville, Spain \\ 3 Department of Plant Biology and Ecology, Facultad de Biología, Universidad de Sevilla, Avda. Reina \\ Mercedes s/n, 41012 Seville, Spain; msanchez85@us.es \\ 4 Institute of Biodiversity and Ecosystem Research, Bulgarian Academy of Sciences, 2 Gagarin Street, \\ 1113 Sofia, Bulgaria; Gergana.Vasileva@iber.bas.bg \\ * Correspondence: ajgreen@ebd.csic.es; Tel.: +34-954-232-340
}

check for

updates

Citation: Redón, S.; Gajardo, G.; Vasileva, G.P.; Sánchez, M.I.; Green,

A.J. Explaining Variation in

Abundance and Species Diversity of Avian Cestodes in Brine Shrimps in the Salar de Atacama and Other Chilean Wetlands. Water 2021, 13, 1742. https://doi.org/10.3390/ w13131742

Academic Editor: Nisikawa Usio

Received: 17 May 2021

Accepted: 21 June 2021

Published: 23 June 2021

Publisher's Note: MDPI stays neutral with regard to jurisdictional claims in published maps and institutional affiliations.

Copyright: (c) 2021 by the authors. Licensee MDPI, Basel, Switzerland. This article is an open access article distributed under the terms and conditions of the Creative Commons Attribution (CC BY) license (https:// creativecommons.org/licenses/by/ $4.0 /)$.

\begin{abstract}
Further biogeographical studies of parasites are vital to improve our understanding of biodiversity distribution and predict the impacts of global change. Hypersaline lakes are good laboratories to investigate the avian cestode abundance and species diversity given the abundance of hosts (waterbirds and Artemia) and their broad latitudinal distribution. We analysed cestode infection in brine shrimp Artemia franciscana in northern (Atacama) and central Chile and compared them to results from $A$. persimilis in southern Chile (Patagonia). Thus, we covered a broad latitudinal gradient from $23^{\circ}$ to $53^{\circ} \mathrm{S}$. Five cestode taxa including two species of the genus Flamingolepis, Gynandrotaenia stammeri, Eurycestus avoceti, and Fuhrmannolepis averini were recorded from A. franciscana in Atacama lagoons (prevalence $=4.1 \%$ ). In contrast, no cestode infection was detected in central Chile, likely because they are temporary wetlands. Parasites of flamingos and shorebirds were associated with Atacama lagoons (arid and higher salinity), while Confluaria podicipina and Fimbriarioides sp. (parasites of grebes and ducks, respectively) were dominant in Patagonian lagoons (sub-antarctic and of lower salinity). These differences mirror changes in the relative abundance of the respective final hosts. The flamingo parasite Flamingolepis sp. 1 was the most prevalent and abundant cestode in Atacama, where it was recorded only in autumn. Seasonality and habitat effects (especially abundance and phenology of different bird species) appear to override any latitudinal trends in the prevalence, diversity, and distribution of cestodes. Cestode prevalence was higher in larger wetlands but was not related to the sex of either intermediate host. We recorded a greater taxonomic richness at the cestode family level in Atacama, but a greater dominance of a single family of avian hosts (the flamingos). Ours is the first spatio-temporal study of Artemia cestodes at local and regional scales in the southern hemisphere.
\end{abstract}

Keywords: Artemia; cestode infection; environmental factors; latitude; hypersaline lagoons; Chile

\section{Introduction}

Knowledge of geographical variation in parasite diversity is crucial for biodiversity conservation, mitigating the impact of emerging diseases, and facilitating the use of parasites as biogeographic indicators [1]. However, owing to contrasting results for different parasite groups (including taxa-specific and scale-dependent patterns) and the scarce parasitological information for many hosts in some regions (such as the tropics) patterns of parasite species diversity, and their drivers remain unclear [2,3]. For example, [4] did a large-scale quantitative study with 950 surveys of helminth endoparasites with different ecology, life cycles and transmission strategies (87\% from the northern hemisphere), including trematodes, cestodes, nematodes and acanthocephalans of fish, mammals, and 
avian hosts, and found no consistent evidence for a latitudinal gradient in species richness (see also [2]). Recent studies have highlighted the interest in reducing the taxonomic level of parasites and hosts (ideally a single widely distributed host species) to gain insights into latitudinal patterns of species diversity [3], but these kinds of studies remain limited. Even less attention has been paid to latitudinal variation in the taxonomic composition of communities, particularly of parasites [4].

The parasite community of a host is expected to change according to the diversity and availability of intermediate and/or final hosts. For avian parasites, distributional patterns have been relatively understudied compared to those with fish or mammalian hosts [4] and have mostly focused on blood parasites (see the review of [5]) such as haemosporidians [6-9]. In particular, little is known for cestodes of aquatic birds, especially in the southern hemisphere. Cestodes are obligate parasites with complex life cycles that involve multiple hosts, usually an invertebrate as intermediate and a vertebrate as the final host. In the hypersaline aquatic ecosystems (such as inland lagoons, salars, and coastal salterns), the cosmopolitan brine shrimp Artemia (Crustacea: Branchiopoda: Anostraca) serves as an intermediate host for cestodes parasitizing waterbirds, with a total of 22 species recorded to date, mostly in the Northern Hemisphere and particularly in the Palaearctic [10]. Artemia becomes infected through the ingestion of eggs from the aquatic environment, developing into a cysticercoid (larval stage or metacestode) which matures and completes the life cycle only after predation by the bird final host. These parasites show high specificity for Artemia and occasionally have been recorded in fairy shrimps, such as Branchinecta spp. [11,12].

Despite recent efforts to extend parasitological data on cestodes from different hosts at a global scale [13], the diversity and life cycles of this group of parasites in South America remain poorly known [10,14-16]. How cestode communities in Artemia are spatially distributed, and how ecological factors can shape variation in species richness, taxonomic composition, and infection levels, remains unclear. Since parasites are dependent on their hosts, both may be expected to follow the same geographical range and spatial patterns [17], but what are the patterns for avian cestodes with a complex life cycle whose final hosts are migratory and therefore change their distribution between seasons? Likewise, what patterns occur in temporary wetlands if parasites have no resting forms to resist desiccation? Given the migratory habits of birds and the limited hydroperiod of certain wetlands, parasite populations may be more affected by season than latitude. Previous studies in the Palaearctic indicate that the composition of cestode communities in Artemia is strongly dependent on the local abundance of their avian final hosts [15,18-20], however, knowledge is limited for the southern hemisphere $[15,16]$.

Chile has a great diversity of hypersaline biotopes over an extreme latitudinal range, ranging from subtropical high-altitude lagoons in the Atacama Desert to sub-Antarctic lagoons in Patagonia, and including permanent inland and coastal lagoons and temporary salterns [21,22]. Two sexual Artemia species are reported: A. franciscana Kellogg, 1906 widely distributed in the American continent (from Canada to $35^{\circ} \mathrm{S}$ in the South Cone of South America) and A. persimilis Piccinelli and Prosdocimi, 1968 restricted to the south of Chile and Argentina [23-26], providing a valuable system to study how parasite distributions vary in and among geographical locations and between congeners. The present study aims to identify the main drivers of local diversity of cestodes in A. franciscana from hypersaline wetlands from northern (Atacama Desert) and central Chile (latitude $23^{\circ}-34^{\circ} \mathrm{S}$ ) and compare the results with those for $A$. persimilis from southern Chile (latitude $50^{\circ}$ S) (see also [15]).

To investigate parasite diversity, we examined the species richness and abundance of the cestode communities and infection levels (prevalence, intensities, and abundance) in Artemia populations. Our main objective was to study how these parameters vary within each area in relation to salinity, wetland size, habitat type, and seasonality. Secondly, the host sex effect was also analysed. Our hypotheses regarding cestode abundance and richness were that both would be: (i) higher at lower latitudes (reflecting a general pattern for other fauna such as aquatic invertebrates; [27]); (ii) higher during the austral summer 
when waterbirds breeding in North America are present in the region; (iii) positively correlated with wetland size (because the diversity and abundance of waterbirds generally increase in larger wetlands, [28]); (iv) negatively related with salinity (since some waterbird hosts avoid wetlands of high salinities, [29]). We also hypothesized that (v) infection rates would be higher in female hosts because they have a longer lifespan (up to $16 \%$ ) than males [30]), increasing their exposure to cestode eggs; and (vi) infection parameters would be higher in A. franciscana than A. persimilis because of its longer lifespan [30]). Finally, the taxonomic composition of cestodes was expected to change between regions due to their different bird communities.

\section{Materials and Methods}

\subsection{Brine Shrimp Populations and Study Sites}

We analysed cestode communities in A. franciscana hosts from northern and central Chile (latitude $23^{\circ} \mathrm{S}$, and $33-34^{\circ} \mathrm{S}$, respectively), and A. persimilis from southern (50-53 ${ }^{\circ}$ S) Chile, and a total of 15 sampling sites with the presence of Artemia in nine of them (Figure 1, Table 1). Sampling included protected areas and wetlands of international importance such as waterbird habitats (Ramsar sites). In the North (Atacama Desert, Antofagasta Region), there were seven study sites, five within the Salar de Atacama at $2300 \mathrm{~m}$ above sea level (m.a.s.l.). These were Tebenquiche (TEB) and four lagoons within the Soncor hydrological system [31]: Barros Negros (BNE), Burro Muerto (BUM), Chaxas (CHA), and Puilar (PUI). We also sampled Salar de Tara (TAR, at 4500 m.a.s.l.) and Salar de Pujsa (PUJ, at 4530 m.a.s.l.) located within Los Flamencos National Reserve which are Ramsar sites due to their importance for a variety of waterbirds, especially the Andean flamingo Phoenicoparrus andinus (Philippi), the Puna flamingo Phoenicoparrus jamesi (Sclater), and the Chilean flamingo Phoenicopterus chilensis Molina [32]. Flamingos are present all year round in the Salar de Atacama, although many individuals disperse to lower altitudes outside the breeding season [33]. The Salar de Atacama is one of the most important breeding sites for the Andean flamingo [22,32], whereas the higher altitude sites are more important for the Puna flamingo. We failed to find Artemia at PUI, TAR and PUJ (which was frozen when visited in June 2018, Table S1).

In Central Chile, we sampled El Convento salterns (CON) (Region of Valparaiso), a shallow temporary water body ( $60 \mathrm{ha},<0.5$ depth) within El Yali National Reserve (Ramsar site), one of the most important sites in Central Chile for Black-necked Swan Cygnus melancoryphus [34]; and 4 artificial coastal saltworks located along the shore of Cáhuil lagoon at the mouth of the Nilahue creek (Region of Libertador Bernardo O'Higgins): Cáhuil (CAH), Lo Valdivia (LOV), La Villa (LAV), and Boyeruca (BOY). We found no Artemia at LAV or BOY (Table S1). Shorebirds, such as Black-necked Stilt Himantopus himantopus ssp. melanurus Vieillot, 1817 and Baird's Sandpiper Calidris bairdii Coues, 1861 were particularly abundant in the area during our visits, but no flamingos were observed.

In the South (Chilean Patagonia, Region of Magallanes and Chilean Antarctica), we sampled three lagoons: Amarga lagoon (AMA) at 80 m.a.s.l. in Última Esperanza Province, and Los Cisnes lagoon (CIS) (Natural Monument) and La Sal lagoon (LLS) both situated in northern Tierra del Fuego, the southernmost distribution of Artemia [15,35]. Only one species of flamingo (the Chilean flamingo) is abundant in Patagonia. We found no Artemia at LLS since it was dry when visited (Table S1). Details of the prevalence and abundance of cestodes for this region and the spatio-temporal dynamics of the infection were previously presented [15] and are not repeated here, but data are used for new analyses (see details in Section 2.5). Data from CIS, the southernmost extreme distribution for A. persimilis, and AMA presented in the previous paper are used here to allow a global view of the cestode biodiversity using Artemia host in Chile and its relation with waterbirds. For the present study, we also include an additional sample of 300 Artemia from AMA collected in November 2017. 


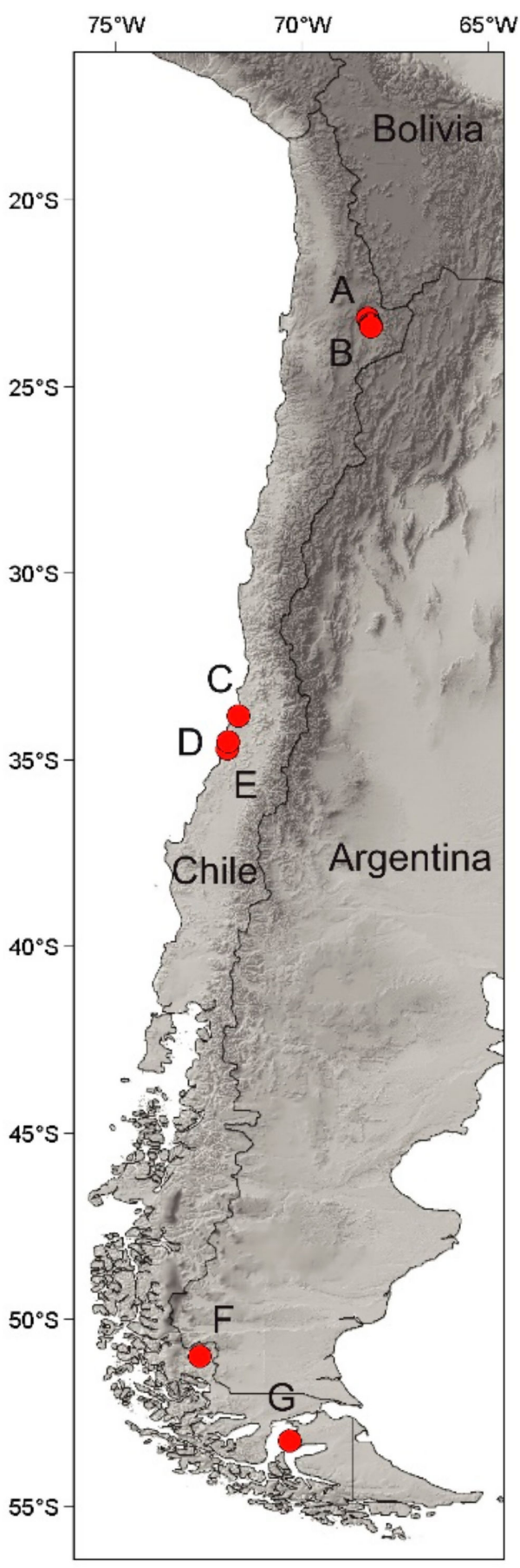

A. Salar de Atacama

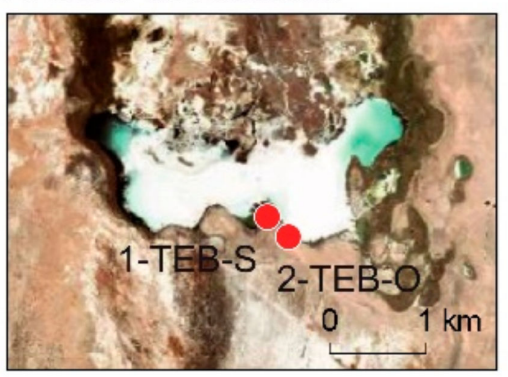

C. El Yali National Reserve

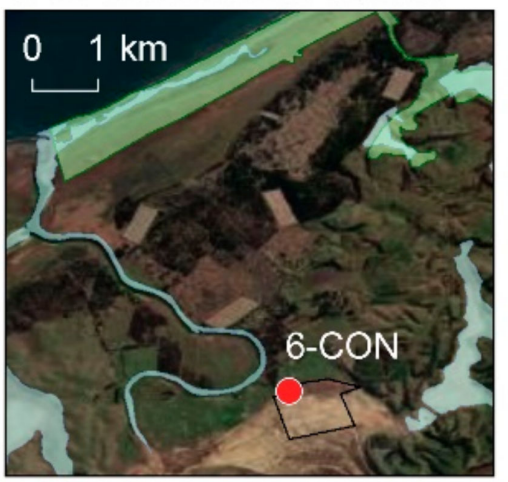

E. Lo Valdivia salterns

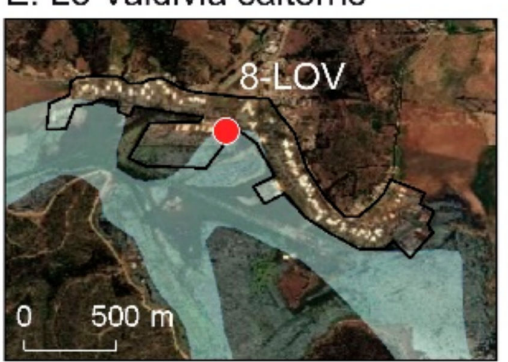

G. Laguna de Los Cisnes Natural Monument

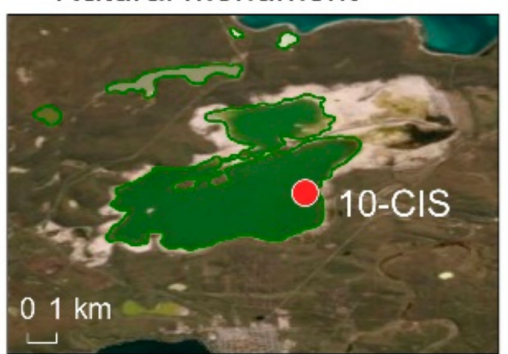

B. Soncor hydrological system (Salar de Atacama)

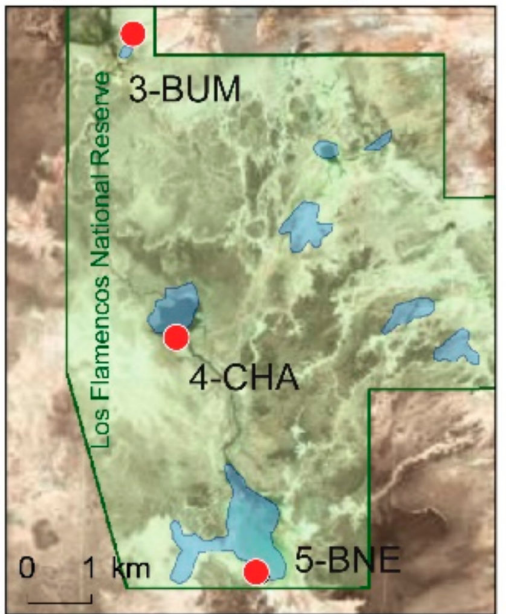

\section{Cáhuil salterns}

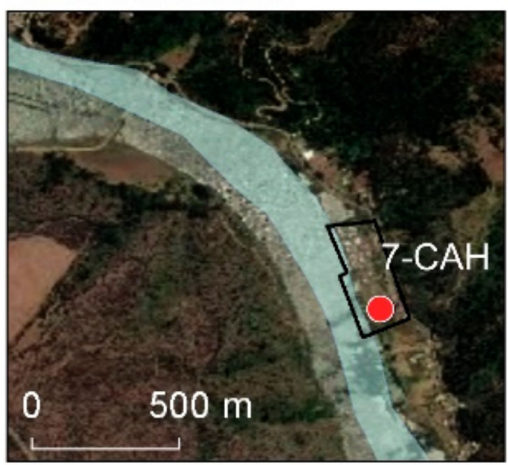

F. Torres del Paine National Park

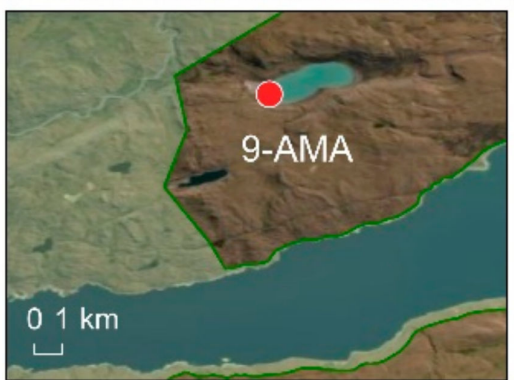

Figure 1. Geographical localisation of study sites along Chile including lagoons from Salar de Atacama in the north (A,B), coastal artificial salterns in the centre (C-E) and Patagonian lagoons in the south $(\mathbf{F}, \mathbf{G})$. Images correspond to close-ups of these seven sampling areas indicating the wetlands where Artemia was collected. 1-TEB-S, Tebenquiche-sendero; 2-TEB$\mathrm{O}$, Tebenquiche-origen; 3-BUM, Burro Muerto pond; 4-CHA, Chaxas lagoon; 5-BNE, Barros Negros lagoon; 6-CON, El Convento salterns; 7-CAH, Cáhuil salterns; 8-LOV, Lo Valdivia salterns; 9-AMA, Amarga lagoon; 10-CIS, Cisnes lagoon. Protected areas Los Flamencos National Reserve, El Yali National Reserve, Torres del Paine National Park and Laguna de Los Cisnes Natural Monument in $(\mathbf{B}, \mathbf{C}, \mathbf{F}, \mathbf{G})$, respectively, are delimited by continuous green lines. Red dots indicate collection points. 


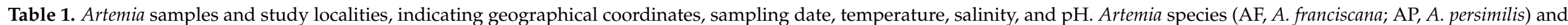
number of individuals examined (n) in each sample are also shown.

\begin{tabular}{|c|c|c|c|c|c|c|c|c|}
\hline Locality & Coordinates & Sampling Date & Temperature $\left({ }^{\circ} \mathrm{C}\right)$ & Salinity $(g / L)$ & $\mathrm{pH}$ & $\begin{array}{c}\text { Depth } \\
\text { (cm) }\end{array}$ & $\begin{array}{l}\text { Size } \\
\text { (ha) }\end{array}$ & Artemia Species (n) \\
\hline \multicolumn{9}{|l|}{ North Chile-II Region-Antofagasta } \\
\hline $\begin{array}{l}\text { Laguna Tebenquiche-Origen TEB-O } \\
\text { (Salar de Atacama, El Loa Province) }\end{array}$ & $\begin{array}{l}23^{\circ} 08^{\prime} 24.7^{\prime \prime} \mathrm{S} \\
68^{\circ} 15^{\prime} 15.2^{\prime \prime} \mathrm{W}\end{array}$ & $\begin{array}{l}3 \text { November } 2017 \\
2 \text { June } 2018\end{array}$ & $\begin{array}{l}20.6 \\
21.0\end{array}$ & $\begin{array}{l}320 \\
180\end{array}$ & $\begin{array}{l}7.4 \\
7.8\end{array}$ & $\begin{array}{l}20 \\
30\end{array}$ & 217 & $\begin{array}{c}\mathrm{AF}^{*} \\
\mathrm{AF}(206)\end{array}$ \\
\hline $\begin{array}{l}\text { Laguna Tebenquiche-Sendero TEB-S } \\
\text { (Salar de Atacama, El Loa Province) }\end{array}$ & $\begin{array}{l}23^{\circ} 08^{\prime} 18.9^{\prime \prime} \mathrm{S} \\
68^{\circ} 15^{\prime} 22.2^{\prime \prime} \mathrm{W}\end{array}$ & $\begin{array}{l}3 \text { November } 2017 \\
2 \text { June } 2018\end{array}$ & $\begin{array}{l}16.0 \\
23.9\end{array}$ & $\begin{array}{l}230 \\
240\end{array}$ & $\begin{array}{l}7.7 \\
7.4\end{array}$ & $\begin{array}{l}20 \\
30\end{array}$ & 217 & $\begin{array}{l}\mathrm{AF}(200) \\
\operatorname{AF}(148)\end{array}$ \\
\hline $\begin{array}{l}\text { Estanque Burro Muerto BUM } \\
\text { (Salar de Atacama, El Loa Province) }\end{array}$ & $\begin{array}{l}23^{\circ} 17^{\prime} 16.5^{\prime \prime} \mathrm{S} \\
68^{\circ} 10^{\prime} 26.4^{\prime \prime} \mathrm{W}\end{array}$ & 1 June 2018 & 13.6 & 60 & 7.8 & 50 & 0.01 & $\operatorname{AF}(200)$ \\
\hline $\begin{array}{l}\text { Laguna Chaxas CHA } \\
\text { (Salar de Atacama, El Loa Province) }\end{array}$ & $\begin{array}{l}23^{\circ} 19^{\prime} 49.9^{\prime \prime} \mathrm{S} \\
68^{\circ} 10^{\prime} 02.9^{\prime \prime} \mathrm{W}\end{array}$ & $\begin{array}{l}5 \text { November } 2017 \\
31 \text { May } 2018\end{array}$ & $\begin{array}{l}21.9 \\
18.6\end{array}$ & $\begin{array}{c}119 \\
80\end{array}$ & $\begin{array}{l}7.9 \\
7.8\end{array}$ & $\begin{array}{l}10 \\
10\end{array}$ & 39 & $\begin{array}{c}\mathrm{AF}^{*} \\
\mathrm{AF}(150)\end{array}$ \\
\hline $\begin{array}{l}\text { Laguna Barros Negros BNE } \\
\text { (Salar de Atacama, El Loa Province) }\end{array}$ & $\begin{array}{l}23^{\circ} 21^{\prime} 51.8^{\prime \prime} \mathrm{S} \\
68^{\circ} 09^{\prime} 20.8^{\prime \prime} \mathrm{W}\end{array}$ & $\begin{array}{l}5 \text { November } 2017 \\
31 \text { May } 2018\end{array}$ & $\begin{array}{l}34.8 \\
15.8\end{array}$ & $\begin{array}{l}200 \\
132\end{array}$ & $\begin{array}{l}7.6 \\
7.7\end{array}$ & $\begin{array}{l}25 \\
25\end{array}$ & 121 & $\begin{array}{c}- \\
\operatorname{AF}(220)\end{array}$ \\
\hline \multicolumn{9}{|l|}{ Central Chile-V Region-Valparaiso } \\
\hline $\begin{array}{l}\text { Salinas de El Convento CON } \\
\text { (Santo Domingo, San Antonio Province) }\end{array}$ & $\begin{array}{c}33^{\circ} 48^{\prime} 00^{\prime \prime} \mathrm{S} \\
71^{\circ} 42^{\prime} 53.4^{\prime \prime} \mathrm{W}\end{array}$ & 4 February 2018 & 25.4 & 320 & 7.6 & 5 & 97 & $\mathrm{AF}^{*}$ \\
\hline \multicolumn{9}{|l|}{$\begin{array}{l}\text { Central Chile-VI Region- Libertador } \\
\text { Bernardo O'Higgins }\end{array}$} \\
\hline $\begin{array}{l}\text { Salinas de Cáhuil CAH (Pichilemu, } \\
\text { Cardenal Caro Province) }\end{array}$ & $\begin{array}{l}34^{\circ} 29^{\prime} 43.7^{\prime \prime} \mathrm{S} \\
71^{\circ} 59^{\prime} 56^{\prime \prime} \mathrm{W}\end{array}$ & 2 February 2018 & 27.6 & 130 & 8.6 & 30 & 7.5 & AF (200) \\
\hline $\begin{array}{l}\text { Salinas de Lo Valdivia (Paredones, } \\
\text { Cardenal Caro Province) }\end{array}$ & $\begin{array}{l}34^{\circ} 41^{\prime} 49.2^{\prime \prime} \mathrm{S} \\
72^{\circ} 00^{\prime} 53.7^{\prime \prime} \mathrm{W}\end{array}$ & 3 February 2018 & 28.0 & 150 & 7.9 & 35 & 69 & $\mathrm{AF}(200)$ \\
\hline \multicolumn{9}{|l|}{$\begin{array}{l}\text { South Chile-XII Region Magallanes } \\
\text { and Chilean Antarctica }\end{array}$} \\
\hline $\begin{array}{l}\text { Laguna Amarga AMA (Última } \\
\text { Esperanza Province) }\end{array}$ & $\begin{array}{l}50^{\circ} 58^{\prime} 22.3^{\prime \prime} \mathrm{S} \\
72^{\circ} 43^{\prime} 58.85^{\prime \prime} \mathrm{W}\end{array}$ & $\begin{array}{l}26 \text { November } 2017 \\
18 \text { April } 2018\end{array}$ & $\begin{array}{c}10.6 \\
-\end{array}$ & $\begin{array}{l}86 \\
81\end{array}$ & $\begin{array}{c}9.2 \\
-\end{array}$ & $\begin{array}{c}25-50 \\
-\end{array}$ & 487 & $\begin{array}{l}\mathrm{AP}(500)^{2} \\
\operatorname{AP}(200)^{1}\end{array}$ \\
\hline $\begin{array}{l}\text { Laguna de Los Cisnes (Porvenir, Tierra } \\
\text { del Fuego Island) }\end{array}$ & $\begin{array}{l}53^{\circ} 14^{\prime} 48.82^{\prime \prime} \mathrm{S} \\
70^{\circ} 21^{\prime} 8.33^{\prime \prime} \mathrm{W}\end{array}$ & $\begin{array}{l}29 \text { November } 2017 \\
17 \text { April } 2018\end{array}$ & 13.7 & $\begin{array}{l}55 \\
51\end{array}$ & $\begin{array}{c}9.1 \\
-\end{array}$ & $\begin{array}{c}15-25 \\
-\end{array}$ & 1561 & $\begin{array}{l}\mathrm{AP}(200)^{1} \\
\mathrm{AP}(200)^{1}\end{array}$ \\
\hline
\end{tabular}

* Samples not checked for parasite infection because of the reduced number of individuals $(<20) ;{ }^{1}$ data from [15]; ${ }^{2}$ data for 200 of these individuals were presented in [15]. 


\subsection{Sampling}

Sampling was conducted in November 2017, February 2018, and May-June 2018 (see details in Table 1 and Table S1) with permission from the National Forest Corporation from Chile (CONAF), local indigenous communities from Atacama, and saltworkers (central Chile). Not all sites were sampled during the three time periods, owing to limited accessibility (e.g., due to waterbird reproductive periods, or extreme weather conditions). Artemia were collected with a hand-net $(180 \mu \mathrm{m}$ mesh) at a constant, slow speed in several points selected at random from different parts of the pond. There was one collecting site per locality per date, except for TEB due to spatial differences in salinity (Table 1). Brine shrimp samples were cleaned with fresh water and preserved in $70 \%$ ethanol. Water salinity was measured with a portable refractometer ATAGO (MASTER 100-H). Water temperature and $\mathrm{pH}$ were measured using a $\mathrm{pH}$ meter model 8100 plus. Geographical coordinates and altitude of sampling sites were registered by GPS (GARMIN 64s). Vectorial information on lagoons/water masses was downloaded from Biblioteca del Congreso Nacional de Chile (BCN) (https://www.bcn.cl/siit/mapas_vectoriales; accessed on 23 July 2020) and manually digitalized over a Google basemap where required (salterns). Surfaces were calculated in WGS 1984 UTM Zone 19S and NSIDC EASE Grid South projections.

\subsection{Parasitological Examination}

Samples of approximately 200 brine shrimps per collection site and date, mostly adult individuals (i.e., with a well-formed hemipenis in males, or ovisac in females) and with an equal sex ratio when possible were analysed. Animals were individually mounted in glycerol and examined with a compound microscope Olympus BX41. Identification of parasites was based on previous morphological descriptions of cestode larvae (i.e., cysticercoids) by $[10,15,36,37]$. For some of the cysticercoids, identification was only possible at a generic level. Molecular identification is required as a future task (manuscript in preparation). Prevalence (P\%, i.e., the percentage of Artemia infected by cestodes in the population), mean intensity (MI, i.e., average number of parasites found in the infected hosts), and mean abundance (MA, i.e., average number of parasites found in the host population) were calculated for the overall infection and for each cestode species, following [38]. For community composition, relative abundance (RA\%) of each cestode species and the total species richness (SR, i.e., the number of cestode species found in each host sample) were indicated.

\subsection{Bird Data}

Information about the presence of birds in the lagoons from Salar de Atacama was extracted from a Biotic Monitoring Report conducted on a regular basis [39] and from ebird data observations provided by ROC (Red de Observadores de Chile) [40], and presented in Table S2. Data were obtained for CHA, BNE, BUM, and TEB during the years of our study (2017 and 2018). No data of similar quality were available for our sites in central and southern Chile.

\subsection{Statistical Analyses}

We analysed the effect of wetland area, salinity, locality, and season on infection parameters and sex effects, using non-parametric statistics due to the lack of normality of the data and dominance of zeros. For A. franciscana, spatial variation was only analysed for the north (Atacama), since no cestode infections were recorded in central Chile. Chisquared tests or Fisher's Exact test were used to compare prevalence among localities, and Kruskal-Wallis and Mann-Whitney $U$ tests to analyse differences in intensity and abundance. In addition, seasonal variations were analysed for $A$. franciscana from TEB (the only locality with enough data for analysis). We used a $Z$ test (for prevalence) and a MannWhitney $U$ test (for intensity and abundance) to compare infection between austral spring (November) and austral autumn ( May-June). Similar statistical analyses were performed to compare infection levels between males and females, separately for $A$. franciscana and $A$. persimilis. No spatio-temporal variations of cestode infection were analysed for $A$. persimilis in the south to avoid overlap with [15]. Additionally, relationships between overall cestode 
prevalence with salinity and wetland size were tested with non-parametrical Kendall correlations. We conducted the above analyses for the overall infection and for each cestode species recorded. Significance was assumed at $p \leq 0.05$. For multiple comparisons, $p$ values were Bonferroni corrected to avoid type I errors. Statistical analyses were conducted in SPSS for Windows version 15.0 (SPSS Inc., Chicago, IL, USA).

\section{Results}

\subsection{Taxonomic Composition of Cestode Communities in Artemia in Chile}

Cyclophyllidean cestodes belonging to 3 families, 6 genera, and 7 species were found (3 of them are apparently new, undescribed species, $[10,15])$. Four species were from the family Hymenolepididae: Confluaria podicipina (CP, parasite of grebes), Fimbriarioides sp. (Fsp, parasite of Anatidae), Flamingolepis sp. 1 and Flamingolepis sp. 2 (Fl-1 and Fl-2, respectively, parasites of flamingos; see $[10,15]$ for morphological descriptions). Other taxa were the dilepidids Eurycestus avoceti (EA, parasite of stilts and avocets) and Furhmannolepis averini (FA, parasite of phalaropes) and the progynotaeniid Gynandrotaenia stammeri (GS, parasite of flamingos).

In the north (Atacama, $23^{\circ} \mathrm{S}$ latitude), Artemia was only found in Salar de Atacama lagoons at relatively high salinities of $80-320 \mathrm{~g} / \mathrm{L}$ (Table 1 ). There, cysticercoids from all three cestode families were recorded in A. franciscana (Table 2), these mainly being parasites of flamingos ( $>88 \%$ ) and parasites of shorebirds (Charadriiformes, $11.5 \%$ ) (Figure 2). Overall, the Fl-1 was the most abundant cestode, representing $80.3 \%$ of the total cysticercoids, followed by FA ( $\mathrm{RA}=8.2 \%$ ). By contrast, no cestode infection was detected in the two A. franciscana populations from artificial saltworks from central Chile ( $34^{\circ} \mathrm{S}$ latitude). In the south (Amarga lagoon, Patagonia, $50^{\circ} \mathrm{S}$ latitude), only A. persimilis occurs at a salinity of $86 \mathrm{~g} / \mathrm{L}$ (Table 1). In this lagoon, only hymenolepidids of grebes and ducks (i.e., $\mathrm{CP}$ and Fsp, respectively) were recorded, with the grebe parasite as the dominant species $(\mathrm{RA}=62.5 \%)$. However, when including previous data from this lagoon and CIS lagoon [15], a total of four cestode species were found to infect $A$. persimilis in the south of Chile with Fl- 1 as the dominant species $(\mathrm{RA}=52.8 \%)$, followed by cestodes of anatids, grebes, and gulls (Figure 2).

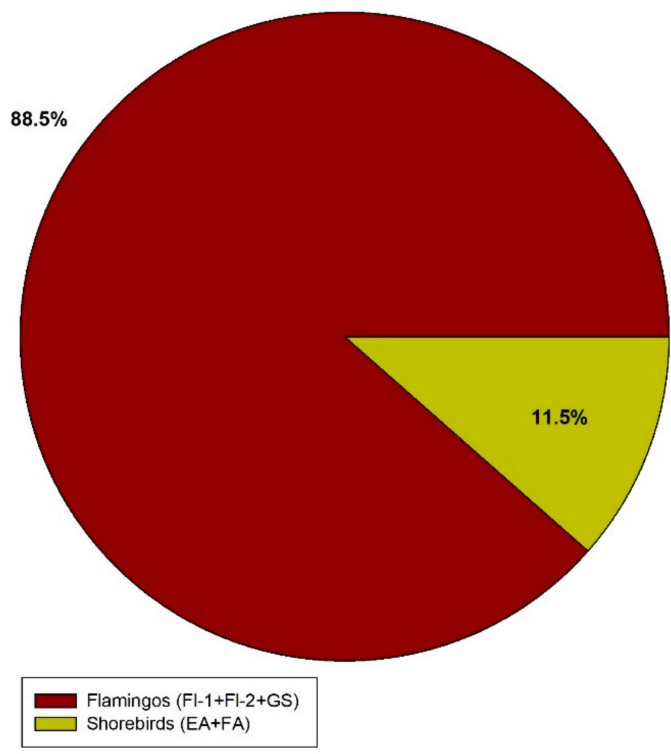

(a)

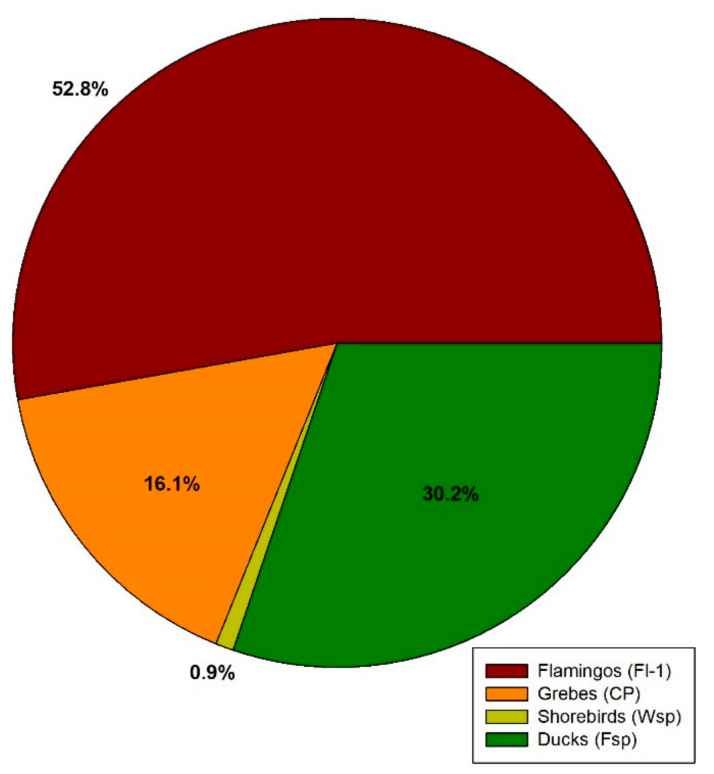

(b)

Figure 2. Relative abundance of cestodes with different avian final hosts found in Artemia intermediate hosts in relation. (a) A. franciscana in the north of Chile (Salar de Atacama lagoons); (b) A. persimilis in the south of Chile (Amarga lagoon and Cisnes lagoon, combining data from this study and from [15]). 


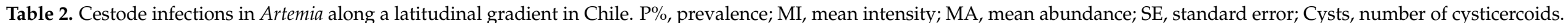

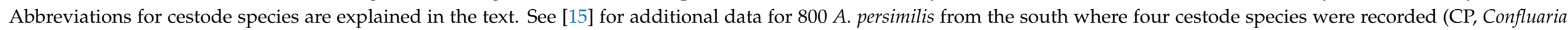
podicipina; Fsp, Fimbriarioides sp.; Fl-1, Flamingolepis sp. 1; Wsp, Wardium sp.) and an overall prevalence of $2.8 \%$ and $20.3 \%$ in AMA and CIS, respectively.

\begin{tabular}{|c|c|c|c|c|c|c|c|c|c|c|c|c|}
\hline \multirow[b]{2}{*}{$\begin{array}{c}\text { Family } \\
\text { Cestode Species }\end{array}$} & \multicolumn{4}{|c|}{$\begin{array}{l}\text { North (Latitude } 23^{\circ} \text { S) } \\
\text { AF-Salar de Atacama }\end{array}$} & \multicolumn{4}{|c|}{$\begin{array}{l}\text { Centre (Latitude } 34^{\circ} \mathrm{S} \text { ) } \\
\text { AF-Coastal Saltworks }\end{array}$} & \multicolumn{4}{|c|}{$\begin{array}{l}\text { South (Latitude } 50^{\circ} \mathrm{S} \text { ) } \\
\text { AP-Amarga Lagoon }\end{array}$} \\
\hline & Cysts & $\mathbf{P} \%$ & $\mathbf{M I} \pm \mathbf{S E}$ & $\mathbf{M A} \pm \mathbf{S E}$ & Cysts & $\mathbf{P} \%$ & $\mathbf{M I} \pm \mathbf{S E}$ & $\mathbf{M A} \pm \mathbf{S E}$ & Cysts & $\mathbf{P} \%$ & $\mathbf{M I} \pm \mathbf{S E}$ & $\mathbf{M A} \pm \mathbf{S E}$ \\
\hline \multicolumn{13}{|l|}{ Hymenolepididae } \\
\hline $\mathrm{CP}$ & 0 & 0.0 & - & 0.00 & 0 & 0.0 & - & 0.00 & 5 & 1.7 & $1.00 \pm 0.00$ & $0.02 \pm 0.01$ \\
\hline Fsp & 0 & 0.0 & - & 0.00 & 0 & 0.0 & - & 0.00 & 3 & 1.0 & $1.00 \pm 0.00$ & $0.01 \pm 0.01$ \\
\hline Fl-1 & 49 & 3.1 & 1.4 & $0.044 \pm 0.01$ & 0 & 0.0 & - & 0.00 & 0 & 0.0 & 0.00 & $0.00 \pm 0.00$ \\
\hline Fl-2 & 3 & 0.3 & $1.00 \pm 0.00$ & $0.003 \pm 0.002$ & 0 & 0.0 & - & 0.00 & 0 & 0.0 & 0.00 & $0.00 \pm 0.00$ \\
\hline \multicolumn{13}{|l|}{ Dilepididae } \\
\hline EA & 2 & 0.2 & $1.00 \pm 0.00$ & $0.002 \pm 0.001$ & 0 & 0.0 & - & 0.00 & 0 & 0.0 & 0.00 & 0.00 \\
\hline FA & 5 & 0.4 & $1.00 \pm 0.00$ & $0.004 \pm 0.002$ & 0 & 0.0 & - & 0.00 & 0 & 0.0 & 0.00 & 0.00 \\
\hline \multicolumn{13}{|l|}{ Progynotaeniidae } \\
\hline GS & 2 & 0.2 & $1.00 \pm 0.00$ & $0.002 \pm 0.002$ & 0 & 0.0 & - & 0.00 & 0 & 0.0 & 0.00 & 0.00 \\
\hline Total & 61 & 4.1 & $1.33 \pm 0.24$ & $0.054 \pm 0.013$ & 0 & 0.0 & - & 0.00 & 8 & 2.7 & $1.00 \pm 0.00$ & $0.027 \pm 0.01$ \\
\hline No. Artemia examined & & 1124 & & & & 400 & & & & 300 & & \\
\hline No. infected & & 46 & & & & 0 & & & & 8 & & \\
\hline
\end{tabular}




\subsection{General Infection Levels}

A total of 1524 A. franciscana individuals were screened for cestodes, and 46 infected individuals were detected (overall prevalence $=3.02 \%, 95 \%$ CI: $2.3-4.0 \%$ ), most of them $(97.8 \%)$ by only one species (single infections), as expected given the low prevalence (Table 2). Multiple species infections were recorded in just one individual (a male infected with Fl-1 + Fl-2). For A. persimilis, 300 individuals were examined, detecting 8 infected individuals (prevalence $=2.7 \%, 95 \%$ CI: $1.4-5.2 \%$ ), all of them infected with just one cysticercoid of CP or Fsp (Table 2, see [15] for results from previous samples).

\subsection{Cestode Distribution in A. franciscana}

In A. franciscana, cestode larvae were only found in inland lagoons from Atacama in the north and were absent at coastal saltworks in the centre. In the north, there was an overall prevalence of $4.1 \%$ (Table 2). Fl-1 was the most prevalent and abundant cestode in the region $\left(23^{\circ} \mathrm{S}\right.$, prevalence $=3.1 \%, 95 \%$ CI: $2.3-4.3 \%$ ) $($ Table 2$)$.

In the Salar de Atacama, infection was detected in autumn (May/June), with prevalence ranging from $1.3 \%$ to $10 \%$, except for BUM where no cestodes were found (Table 3, Figure 3). No cestodes were detected in spring. Significant differences among localities were detected for the overall prevalence $\left(\chi^{2}=27.563, \mathrm{df}=3, p<0.001, \mathrm{~V}=0.17\right.$; Figure 3 ) and abundance $(H(3)=27.437, p<0.001)$, as well as for Fl-1 $\left(\chi^{2}=24.572, \mathrm{df}=3, p<0.001\right.$, $\mathrm{V}=0.16$; Table 3 ). The intensity of infection did not vary (Table 3 ). Infection by FA was only recorded at TEB (Table 3) and at the highest salinity (Table 4). When comparing spring and autumn infection from TEB at the same collection point (i.e., TEB-S), we detected a seasonal effect for FA (the only cestode present) with higher prevalence $(Z=2.173, p=0.03$ ) and abundance $(U=14,300, p=0.009)$ in June (austral autumn) than November (austral spring). The cestode species richness per locality ranged from 1 to 4 (Table 3).

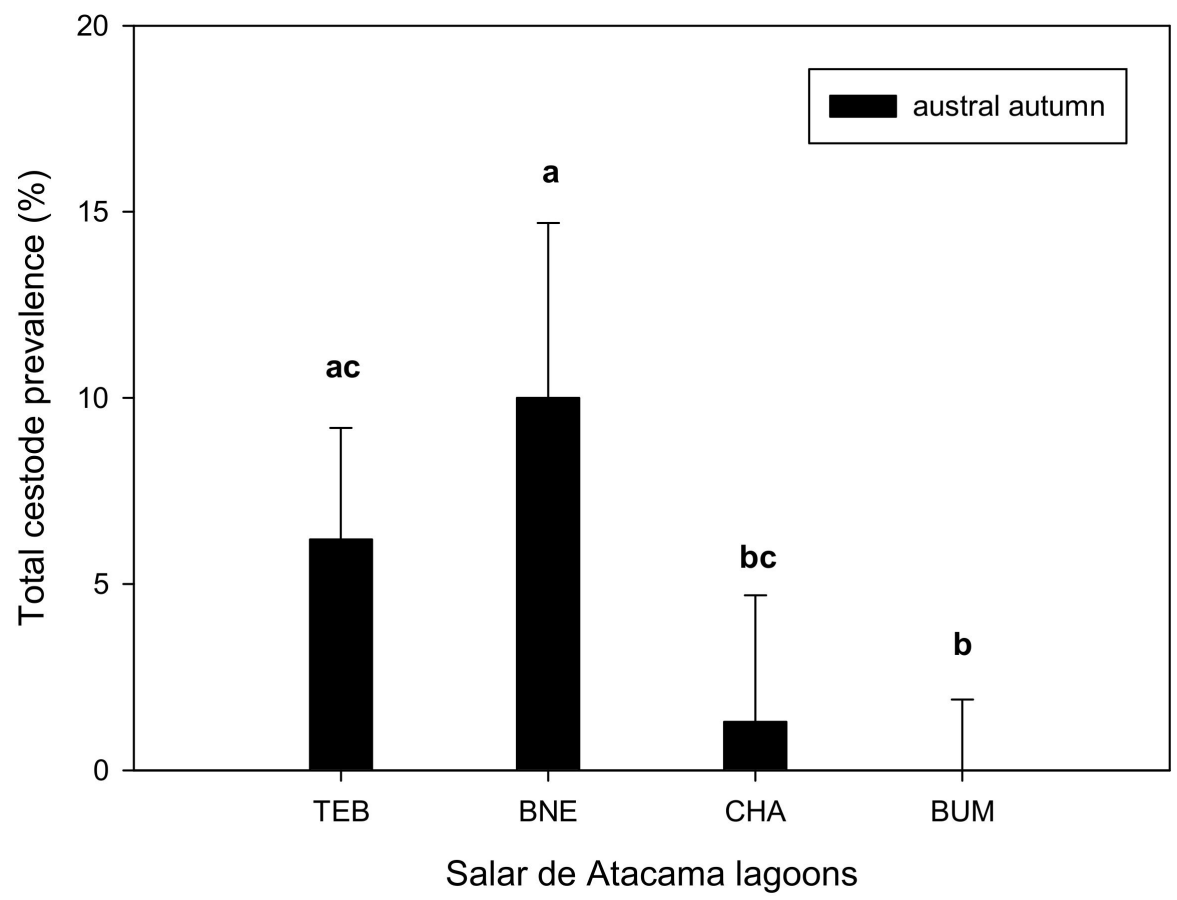

Figure 3. Prevalence of cestode infection in A. franciscana from several localities in Salar de Atacama (north of Chile) in austral autumn. Bars show upper 95\% confidence intervals. TEB, Tebenquiche; BNE, Barros Negros; CHA, Chaxas; BUM, Burro Muerto. Different lower letters indicate statistical differences among sites after Post Hoc procedures with Bonferroni correction. 


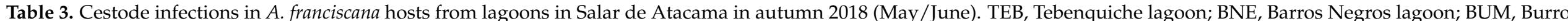

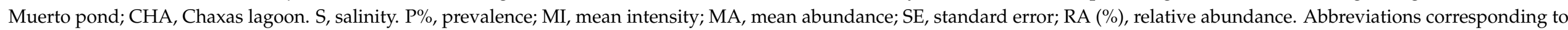

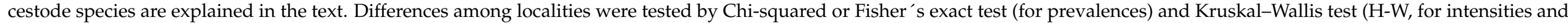
abundances). Different superscript letters denote statistical differences after Post Hoc procedures with Bonferroni correction for multiple comparisons.

\begin{tabular}{|c|c|c|c|c|c|c|c|}
\hline \multicolumn{8}{|c|}{ Localities } \\
\hline Cestode Species & & $\begin{array}{c}\text { TEB } \\
\mathrm{S}=180-240 \mathrm{~g} / \mathrm{L}\end{array}$ & $\begin{array}{c}\text { BNE } \\
\mathrm{S}=132 \mathrm{~g} / \mathrm{L}\end{array}$ & $\begin{array}{c}\text { CHA } \\
\mathrm{S}=80 \mathrm{~g} / \mathrm{L}\end{array}$ & $\begin{array}{c}\text { BUM } \\
\mathrm{S}=60 \mathrm{~g} / \mathrm{L}\end{array}$ & $x^{2}$ & K-W (H) \\
\hline \multirow[t]{4}{*}{ Fl-1 } & $\mathrm{P} \%$ & $4.0^{\mathrm{ab}}$ & $8.6^{b}$ & $1.3^{\mathrm{a}}$ & $0.0^{\mathrm{a}}$ & $24.572 * *$ & \\
\hline & $\mathrm{MI} \pm \mathrm{SE}$ & $1.93 \pm 0.71$ & $1.05 \pm 0.05$ & $1.00 \pm 0.00$ & - & & 3.909 \\
\hline & $\mathrm{MA} \pm \mathrm{SE}$ & $0.08 \pm 0.03^{\mathrm{ac}}$ & $0.09 \pm 0.02^{\mathrm{a}}$ & $0.013 \pm 0.01 \mathrm{bc}$ & $0.00^{b}$ & & $24.388^{* *}$ \\
\hline & RA (\%) & 75 & 86.4 & 100 & 0.0 & & \\
\hline \multirow[t]{3}{*}{ Fl-2 } & $\mathrm{P} \%$ & 0.8 & 0.0 & 0.0 & 0.0 & 2.710 & \\
\hline & $\mathrm{MA} \pm \mathrm{SE}$ & $0.009 \pm 0.01$ & 0.00 & 0.00 & 0.00 & & 4.841 \\
\hline & RA (\%) & 8.3 & 0.0 & 0.0 & 0.0 & & \\
\hline \multirow[t]{4}{*}{ EA } & $\mathrm{P} \%$ & 0.3 & 0.5 & 0.0 & 0.0 & 1.557 & \\
\hline & $\mathrm{MI} \pm \mathrm{SE}$ & 1.00 & 1.00 & - & - & & 0.000 \\
\hline & $\mathrm{MA} \pm \mathrm{SE}$ & $0.003 \pm 0.003$ & $0.005 \pm 0.00$ & 0.00 & 0.00 & & 1.407 \\
\hline & RA (\%) & 2.8 & 4.5 & 0.0 & 0.0 & & \\
\hline \multirow[t]{2}{*}{ FA } & $\mathrm{P} \%$ & 1.4 & 0.0 & 0.0 & 0.0 & 5.047 & \\
\hline & $\mathrm{MI} \pm \mathrm{SE}$ & $1.00 \pm 0.00$ & - & - & - & & no test \\
\hline \multirow[t]{4}{*}{ GS } & $\mathrm{P} \%$ & 0.0 & 0.9 & 0.0 & 0.0 & 3.904 & \\
\hline & $\mathrm{MI} \pm \mathrm{SE}$ & - & $1.00 \pm 0.00$ & - & - & & no test \\
\hline & $\mathrm{MA} \pm \mathrm{SE}$ & 0.00 & $0.009 \pm 0.01$ & 0.00 & 0.00 & & 6.407 \\
\hline & RA (\%) & 0.0 & 9.1 & 0.0 & 0.0 & & \\
\hline \multirow[t]{3}{*}{ Total } & $\mathrm{P} \%$ & $6.2^{\mathrm{ac}}$ & $10^{\mathrm{a}}$ & $1.3^{b c}$ & $0.0^{\mathrm{b}}$ & $27.563 * *$ & \\
\hline & $\mathrm{MI} \pm \mathrm{SE}$ & $1.64 \pm 0.5$ & $1.05 \pm 0.05$ & $1.00 \pm 0.00$ & - & & 2.730 \\
\hline & $\mathrm{MA} \pm \mathrm{SE}$ & $0.10 \pm 0.04^{a}$ & $0.11 \pm 0.02^{\mathrm{a}}$ & $0.013 \pm 0.01^{b}$ & $0.00^{\mathrm{b}}$ & & $27.437 * *$ \\
\hline \multicolumn{2}{|l|}{ No. cestodes } & 36 & 23 & 2 & 0 & & \\
\hline \multicolumn{2}{|c|}{ No. Artemia examined } & 354 & 220 & 150 & 200 & & \\
\hline
\end{tabular}

${ }^{*}$ Indicates significant differences at $p<0.05,{ }^{* *}$ indicates significant differences at $p<0.001 ;$ no test-test was not possible because the species was only recorded in one locality. 
Table 4. Cestode infections in relation to high salinity in A. franciscana samples from Tebenquiche lagoon, Salar de Atacama (Northern Chile), collected in austral autumn (02 June 2018). Abbreviations corresponding to cestode species are explained in the text. P\%, prevalence; MI, mean intensity; MA, mean abundance; SE, standard error; RA (\%), relative abundance; SR, species richness. $Z$ test and Mann-Whitney $U$ test were used for comparing infective parameters. Significantly higher values are in bold.

\begin{tabular}{|c|c|c|c|c|c|c|}
\hline Cestode Species & & $\begin{array}{c}\text { TEB-S } \\
S=240 \mathrm{~g} / \mathrm{L}\end{array}$ & $\begin{array}{c}\text { TEB-O } \\
S=180 \mathrm{~g} / \mathrm{L}\end{array}$ & Z & $\mathbf{U}$ & $p$-Value \\
\hline \multirow[t]{4}{*}{ Fl-1 } & $\mathrm{P} \%$ & 0.0 & 6.8 & 2.961 & & 0.003 \\
\hline & $\mathrm{MI} \pm \mathrm{SE}$ & - & $1.93 \pm 0.71$ & & no test & - \\
\hline & $\mathrm{MA} \pm \mathrm{SE}$ & 0.00 & $0.013 \pm 0.06$ & & 14,208 & 0.001 \\
\hline & RA (\%) & 0.0 & 87.1 & & & \\
\hline \multirow[t]{4}{*}{ Fl-2 } & $\mathrm{P} \%$ & 0.0 & 1.5 & 0.917 & & 0.359 \\
\hline & $\mathrm{MI} \pm \mathrm{SE}$ & - & $1.00 \pm 0.00$ & & no test & - \\
\hline & $\mathrm{MA} \pm \mathrm{SE}$ & 0.00 & $0.015 \pm 0.01$ & & 15,022 & 0.195 \\
\hline & RA (\%) & 0.0 & 9.7 & & & \\
\hline \multirow[t]{4}{*}{ EA } & $\mathrm{P} \%$ & 0.0 & 0.5 & -0.139 & & 0.890 \\
\hline & $\mathrm{MI} \pm \mathrm{SE}$ & - & 1.00 & & no test & - \\
\hline & $\mathrm{MA} \pm \mathrm{SE}$ & 0.00 & $0.005 \pm 0.005$ & & 15,170 & 0.579 \\
\hline & RA (\%) & 0.0 & 3.2 & & & \\
\hline \multirow[t]{4}{*}{ FA } & $\mathrm{P} \%$ & 3.4 & 0.0 & 2.210 & & 0.027 \\
\hline & $\mathrm{MI} \pm \mathrm{SE}$ & $1.00 \pm 0.00$ & - & & no test & - \\
\hline & $\mathrm{MA} \pm \mathrm{SE}$ & $0.025 \pm 0.01$ & 0.00 & & 14,729 & 0.011 \\
\hline & RA (\%) & 100 & 0.0 & & & \\
\hline \multirow[t]{4}{*}{ Total } & $\mathrm{P} \%$ & 3.4 & 8.3 & 1.656 & & 0.098 \\
\hline & $\mathrm{MI} \pm \mathrm{SE}$ & $1.00 \pm 0.00$ & $1.8 \pm 0.64$ & & 32.5 & 0.325 \\
\hline & $\mathrm{MA} \pm \mathrm{SE}$ & $0.025 \pm 0.01$ & $0.15 \pm 0.06$ & & 14,491 & 0.028 \\
\hline & SR & $0.03 \pm 0.015$ & $0.09 \pm 0.02$ & & 14,498 & 0.036 \\
\hline No. cestodes & & 5 & 31 & & & \\
\hline No. Artemia examined & & 148 & 206 & & & \\
\hline
\end{tabular}

- Denotes no available data.

\subsection{Bird Data}

Differences between the north and south in the cestode communities were consistent with differences in the abundance of avian final hosts. In particular, grebes and Anatidae were far more abundant in Patagonian [15] than in Atacama wetlands (Table S2), and their cestodes were only recorded in the Artemia from the former wetlands (Figure 2). In the Atacama region, 15 waterbird species were recorded from Salar de Atacama (Table S2). During the years of our study (2017-2018), the most abundant waterbirds were the three flamingo species (Phoenicoparrus andinus, P. jamesi, and Phoenicopterus chilensis), and the following shorebirds (Charadriiformes): Phalaropus tricolor, Tringa flavipes, Calidris bairdii, Charadrius alticola, and Recurvirostra avoceta. In the three localities where we found parasites (i.e., CHA, BNE, and TEB, Table 3), the relative abundance of both groups of waterbirds at each locality in 2018 (when infection was detected) matches the relative abundance of cestodes of flamingos (Fl-1, Fl-2, GS) and shorebirds (EA, FA) recorded in the brine shrimp populations. In CHA where we found Fl-1, the waterbird community was dominated by flamingos (94.2\%). In contrast, in BNE and TEB where $21.4-28.2 \%$ of the birds were shorebirds, EA and FA were also detected.

\subsection{Wetland Size and Salinity Effects}

In Atacama, there was generally a higher cestode prevalence at higher salinities of $>100 \mathrm{~g} / \mathrm{L}$ (Table 3). However, wetlands with a larger surface area were also higher in salinity (Table 1), so it was not possible to separate these effects. The absence of cestodes from BUM 
may be related to its tiny surface area $\left(107 \mathrm{~m}^{2}\right)$, which makes it unattractive for waterbirds. Considering all localities in Chile with a minimum of 100 Artemia individuals (including data from [15]), overall prevalence was positively correlated to wetland size $(\tau=0.479$, $p$ (one-tailed) $<0.05$ ), supporting our initial hypothesis. In contrast, the overall correlation between prevalence and salinity was not significant $(\tau=-0.127, p$ (one-tailed $)=0.288$ ).

\subsection{Sex Effects}

There were no statistically significant differences between males and females in the prevalence, abundance, or intensity of cestode infection for either Artemia species (Table S3).

\section{Discussion}

We conducted the most comprehensive study to date of cestode communities in southern hemisphere brine shrimps, including both New World species. We explored spatio-temporal and local variation in species richness, taxonomic composition, and infection levels along the latitudinal gradient in Chile, one of the least explored areas for the biodiversity of cestodes infecting aquatic birds [14].

\subsection{Latitudinal, Regional, and Local Effects on Cestode Communities}

We found marked differences in the taxonomic composition of the cestode communities between latitudes and host species (A. franciscana and A. persimilis). We found evidence that local environmental factors such as wetland area or salinity, which can influence both intermediate and final hosts, are more relevant for the infection and species richness of cestodes than the latitude at which the host lives. We also found evidence for strong seasonality, which is likely to reflect seasonality in the abundance of both hosts. Studies in other host-parasite systems for helminths with aquatic intermediate hosts, such as marine snails and trematodes, highlight the role of local factors in determining species richness and prevalence of infection [41,42]. We observed taxonomic variation when comparing north and south, with only records for hymenolepidids in the south while cestodes of three families were found in the north. In contrast, a higher diversity of final hosts was observed in the south, where cestodes of grebes, Anatidae, flamingos and shorebirds were found.

We found a geographical discontinuity in the distribution of cestodes in the central region where no infections were detected, which could be explained by habitat type (artificial saltworks) and specific local conditions. The survivorship and the life span of the intermediate host are crucial for both parasite development and transmission to the final host. The presence of Artemia in artificial salterns is strongly affected by saltwork operations (e.g., water circulation among ponds along an increasing salinity gradient until crystallization). The activity of these salterns from Central Chile is restricted to summer months, and during the rest of the year the area remains flooded by tidal dynamics and winter rains, and consequently, Artemia populations disappear. In contrast, the lagoons of the Salar de Atacama and Patagonia are permanent and have a less direct impact from human activities. The unstable and stressful habitat provided by these coastal saltworks could explain the lack of cestodes in their Artemia. Further studies are required to clarify the causes for this apparent hiatus in the geographical distribution of cestodes, and the potential influence of the hydrological characteristics of this seasonal system (estuary in winter and lagoon in summer; [43]).

The differences in the prevalence of some cestodes between regions (north and south) and seasons are likely related to differences in abundance and phenology of their avian final hosts. Prevalence can vary greatly from one month to another, and from one pond to another, in relation to differences in the waterbird communities present, as shown for native and alien Artemia species in Europe [18,44]. Salinity is also likely to have played a major role in our results, as it influences the waterbird communities. The Salar de Atacama holds a complex of high salinity wetlands [31], with a bird community dominated by flamingos and shorebirds (Table S2). In the shallow saline lakes of the Atacama Desert, finding parasites of these two avian groups, such as the genera Flamingolepis or Fuhrmannolepis, was 
predictable. Lower salinity wetlands in other parts of the Andes are much more important for grebes, ducks, and other birds less tolerant of high salinities [45]. The potential hosts for the shorebird cestodes (based on their local abundance and feeding habits in Atacama) include the sedentary Andean avocet Recurvirostra andina Philippi \& Landbeck, together with boreal migratory species such as Wilson's phalarope Phalaropus tricolor (Vieillot), Baird's sandpiper Calidris bairdii Coues, and the lesser yellowlegs Tringa flavipes Gmelin (Table S2). Wilson's phalarope feed on brine shrimps and calanoid copepods, solitarily or in association with the Chilean flamingo [46,47]. By June, almost all the migrants have left to North America to breed, so the cestodes we found in Artemia at that time in Atacama are more likely to parasitize sedentary species such as the avocet. In contrast, in the lower salinity wetlands in Patagonia, ducks, gulls, several grebe species are abundant [48-51]. A previous study in Epecuén lagoon in Argentina evidenced a strong relationship between the abundance of the grebe parasite C. podicipina in A. persimilis and the abundance of the silvery grebe Podiceps occipitalis Garnot final hosts [16].

The Chilean flamingo is the only flamingo species abundant in Patagonia, and only one cestode parasitizing flamingos was detected there (Fl-1, in Cisnes lagoon [15]). Our contrasting result in Atacama raises the possibility that Fl-2 and GS parasitize the Andean and/or the Puna flamingo, which are more abundant in Atacama, although their diets are largely based on diatoms [52]. However, a differential susceptibility of $A$. franciscana and A. persimilis to flamingo parasites, rather than different final hosts, could be an alternative explanation. For example, in European salterns, A. franciscana is more susceptible to Flamingolepis flamingo than to the congener F. liguloides [19,44]. Further research is necessary for a better knowledge of parasite life cycles, their specificity, and the role of bird migration in the composition of neotropical helminth communities. One approach to investigating this would be metabarcoding of faeces collected from waterbirds at our study sites [53].

It remains possible that other environmental factors such as altitude, temperature, $\mathrm{pH}$, ionic composition, or ultraviolet light intensity may contribute to the regional differences in cestode prevalence. The north (subtropical) and south (sub-antarctic) of Chile provide quite different conditions, including a much higher altitude in the north. For instance, our results indicated a lower prevalence of Fl- 1 in the north (1.3-8.6\%, in autumn, present study) than in the south (27.5\% in spring in the Cisnes lagoon, [15]), which has cooler daytime temperatures, lower salinity, and higher $\mathrm{pH}$ than in the north (Tables 1 and 2). In contrast, a higher prevalence was detected in the north for other cestode species such as FA.

Another potential explanation for the differential infections between north and south lies in differences in growth rate or other life-history traits of the two Artemia hosts. The faster development of $A$. franciscana compared to A. persimilis [54] could reduce its period of parasite exposition, explaining the lower prevalence of infection of the former. Spatial variation in the dynamics of the intermediate host may also affect parasite development. Patterns of parasite distribution infecting Artemia could be determined by temperature-salinity profiles, the main factors modulating Artemia populations [55]. The salinity recorded in Salar de Atacama lagoons (reaching a maximum of $320 \mathrm{~g} / \mathrm{L}$ at TEB lagoon) is close to the upper limit tolerated by Artemia (340 g/L in solar ponds, [56]) with just a few observations in nature exceeding that limit [57]. High salinity entails osmotic stress, low oxygen, and desiccation, affecting Artemia performance and likely its role as suitable hosts for parasites since cestode development depends on host size and host resources. However, at low-medium salinities (such as those recorded in Patagonian lagoons), Artemia can coexist with other zooplankters such as the copepod Boeckella poopoensis [58,59], thus increasing both food availability for aquatic birds and the presence of potential intermediate hosts for parasites.

\subsection{The Effects of Season and Host Sex on Cestode Populations}

We found seasonal variation in infection levels in A. franciscana in Salar de Atacama, as previously observed in the congener A. persimilis from Patagonian lagoons [15]), but with opposing trends. In the south, higher prevalence was detected in spring than autumn [15], 
whereas in the north cestodes were recorded only in autumn (present study). The dynamics of aquatic birds could explain these seasonal variations since most final hosts use wetlands in Atacama and/or Patagonia during specific periods of time according to their migratory movements. Several species of Nearctic shorebirds migrate to Chile during the arctic winter and the austral summer (December-February). For instance, Wilson's phalaropes are abundant in high Andean lagoons in the austral summer, which could explain the presence of FA in samples from the austral autumn. Therefore, effects of the season and region might be expected for parasites of birds migrating long distances between North and South America, such as phalaropes, as well as for species that migrate within the country among biogeographical regions. The widespread presence of the flamingo parasites Fl- 1 in the south [15] and north, but in different seasons, may be explained by regional migratory movements of the Chilean flamingo (a common winter visitor in Patagonian lagoons, but which migrates to northern Chile and Argentinean Patagonia for breeding [49,50,60]). Many of the Chilean flamingos in Atacama move to lower altitudes during the austral winter [32], potentially explaining the abundance of Fl-1 in austral spring in CIS [15] and its presence in Salar de Atacama in autumn (present study).

Considering the short developmental time from oncosphere to full cysticercoid inside Artemia (around 15 days for C. podicipina in experimental tests, [61]) and how infection may happen during the whole life cycle of the brine shrimps from metanauplii to adults [62], a parasite can remain alive in the crustacean host practically to the end of its life span i.e., several months (Redón, S. personal observations). Hence, cestodes in Artemia may be able to infect migrant birds that arrive months after the moment of our sampling.

We found no evidence that the sex of the host influences the prevalence of avian cestodes in Artemia, despite differences in life span between males and females shrimps. Studies in Mediterranean salterns found similar results in native A. salina from Spanish and Algerian populations $[18,63]$ and in alien A. franciscana populations from invaded salterns from Spain $[20,46]$.

\subsection{Relationship with North American Cestodes}

Although relatively few studies of cestodes in anostracans have been conducted in North America, our results allow an interesting comparison between the two continents. Flamingos have a limited distribution in North America and do not occur in areas where parasites infecting Artemia have been studied, so it is no surprise that flamingo cestodes have so far only been recorded in Chilean Artemia. However, except for Fimbriarioides sp., all the other cestodes recorded by us or [15] in Chile have already been cited in North America (from intermediate or final hosts).

The dispersal abilities of the final hosts are likely to explain the biogeography of cestodes recorded in the intermediate host. The interhemispheric migratory movements of shorebirds (migrating to Chile from breeding grounds in North America) might explain the common presence of the genera Fuhrmannolepis, Eurycestus and Wardium (parasites of Charadriiformes) in both continents. In the case of C. podicipina, its ability to infect closely related species of grebes (such Podiceps nigricollis in North America and P. occipitalis in Chile) and Artemia (A. franciscana in the USA and A. persimilis in Chile) ([20], the present study, [37]) could explain its wider distribution in the Americas. No grebe species migrates between North and South America, so we may expect the C. podicipina populations in each continent to be genetically divergent. Wardium sp. from A. persimilis in Patagonia [15] is considered the same species as that recorded in A. franciscana in Great Salt Lake, Utah [15]. Unlike other gulls breeding in North America, Franklin's gull Leucophaeus pipixcan migrates to coastal Chile during the northern winter, and this may allow the exchange of this cestode between continents. Future molecular studies should address the phylogeography of the cestodes recorded in our study. For example, based on our understanding of bird migrations, we may predict that the E. avoceti and F. averini populations in Chile and North America are more closely related than the C. podicipina populations, and that the Wardium sp. are somewhat intermediate. 


\section{Conclusions}

Our results provide novel information on how environmental gradients affect parasite infection dynamics and diversity in natural populations of avian cestodes. Our study reveals latitudinal variation in the taxonomic composition of the cestode communities, with exclusive presence of dilepidids of shorebirds in A. franciscana in the north and exclusive presence of hymenolepidids of grebes and anatids infecting A. persimilis in the south. Seasonality and local ecological factors such as salinity and wetland size have strong effects on cestode prevalence and abundance. Future studies are needed to understand how avian cestodes are distributed at macroecological scales, and how they respond to global change such as ongoing salinization of wetlands [64], and changing migration patterns of waterbirds [65].

Supplementary Materials: The following are available online at https:/ /www.mdpi.com/article/ 10.3390/w13131742/s1, Table S1: Details of hypersaline aquatic ecosystems from Chile where no Artemia were found during the sampling visits, Table S2: Waterbird abundance in Salar de Atacama lagoons during 2017 and 2018, Table S3: Comparative infection levels between males and females for A. franciscana hosts from Salar de Atacama lagoons and A. persimilis hosts from Patagonian lagoons in Chile.

Author Contributions: Conceptualization, S.R., M.I.S. and A.J.G.; Formal Analysis, S.R.; Funding Acquisition, S.R., G.G., and A.J.G.; Investigation: S.R. and G.P.V.; Methodology, S.R., M.I.S., A.J.G., and G.P.V.; Project Administration: S.R.; Resources: G.G. and G.P.V.; Visualization: S.R.; Writing-Original Draft Preparation, S.R.; Writing—Review and Editing, S.R., G.G., M.I.S., G.P.V., and A.J.G.; Supervision, A.J.G. and G.G.; All authors have read and agreed to the published version of the manuscript.

Funding: This research was funded by the Comisión Nacional de Investigación Científica y Tecnológica de Chile (CONICYT; now ANID, Agencia Nacional de Investigación y Desarrollo) through the Fondo Nacional de Desarrollo Científico y Tecnológico (FONDECYT, Project 3170939 lead by S.R.). S.R. was supported by Fondecyt postdoctoral fellowship, Postdoctoral contract by Junta de Andalucía and European Social Fund (PAIDI-DOCTOR 01221, ESF) and by Spanish National Plan project CGL2016-76067-P (AEI/FEDER, EU) to A.J.G. The APC was funded by the University of Los Lagos, Chile and CSIC, Spain.

Institutional Review Board Statement: Not applicable.

Informed Consent Statement: Not applicable.

Data Availability Statement: Data generated and analysed during this study are contained within the article and its Supplementary Materials. Raw datasets are available from the corresponding author upon reasonable request, and in Redón et al. 2019 (reference [15]).

Acknowledgments: We are grateful to Corporación Nacional Forestal (CONAF) for providing permission for research activities in the protected areas and for logistic support in Los Flamencos National Reserve, as well as to Indigenous Communities from Atacama and saltworkers from Central Chile who authorized the collection of samples, particularly Jorge Alvares, Adela Catur Mamani, Rafael Moraga and Luis Fernando Soto Retamal. We are especially grateful to Alejandro Cruz, Marcos Cortés, and Vicente Pizarro (CONAF staff), Patricia Beristain (Universidad de Los Lagos), and Rafael Rodríguez (Instituto de Acuicultura Torre la Sal) for assistance during field work, and professor Boyko B. Georgiev (IBER-BAS) for helping with cestode identifications. The Remote Sensing and GIS Laboratory of Estación Biológica de Doñana, CSIC (LAST-EBD), particularly Isabel Afán, assisted with Figure 1 and measures of wetland size. Many thanks to Red de Observadores de Chile (ROC) and several people for their support in obtaining bird data.

Conflicts of Interest: The authors declare no conflict of interest. 


\section{References}

1. Brooks, D.R.; Hoberg, E.P. Triage for the Biosphere: The Need and Rationale for Taxonomic Inventories and Phylogenetic Studies of Parasites. Comp. Parasitol. 2000, 67, 1-25.

2. Poulin, R. Latitudinal gradients in parasite diversity: Bridging the gap between temperate and tropical areas. Neotrop. Helminthol. 2010, 4, 169-177.

3. Preisser, W. Latitudinal gradients of parasite richness: A review and new insights from helminths of cricetid rodents. Ecography 2019, 42, 1315-1330. [CrossRef]

4. Poulin, R.; Leung, T.L.F. Latitudinal gradient in the taxonomic composition of parasite communities. J. Helminthol. 2011, 85, 228-233. [CrossRef]

5. Sehgal, R.N. Manifold habitat effects on the prevalence and diversity of avian blood parasites. Int. J. Parasitol. Parasites Wildl. 2015, 4, 421-430. [CrossRef]

6. Merino, S.; Moreno, J.; Vásquez, R.A.; Martínez, J.; Sánchez-Monsálvez, I.; Estades, C.F.; Ippi, S.; Sabat, P.; Rozzi, R.; Mcgehee, S. Haematozoa in forest birds from southern Chile: Latitudinal gradients in prevalence and parasite lineage richness. Austral Ecol. 2008, 33, 329-340. [CrossRef]

7. Clark, N.J. Phylogenetic Uniqueness, Not Latitude, Explains the Diversity of Avian Blood Parasite Communities Worldwide. Glob. Ecol. Biogeogr. 2018, 27, 744-755. [CrossRef]

8. Cuevas, E.; Vianna, J.A.; Botero-Delgadillo, E.; Doussang, D.; González-Acuña, D.; Barroso, O.; Rozzi, R.; Vásquez, R.A.; Quirici, V. Latitudinal gradients of haemosporidian parasites: Prevalence, diversity and drivers of infection in the Thorn-tailed Rayadito (Aphrastura Spinicauda). Int. J. Parasitol. Parasites Wildl. 2020, 11, 1-11. [CrossRef]

9. Fecchio, A.; Bell, J.A.; Bosholn, M.; Vaughan, J.A.; Tkach, V.V.; Lutz, H.L.; Cueto, V.R.; Gorosito, C.A.; González-Acuña, D.; Stromlund, C.; et al. An inverse latitudinal gradient in infection probability and phylogenetic diversity for Leucocytozoon blood parasites in New World birds. J. Anim. Ecol. 2020, 89, 423-435. [CrossRef]

10. Redón, S.; Vasileva, G.P.; Georgiev, B.B.; Gajardo, G. Exploring parasites in extreme environments of high conservational importance: Artemia franciscana (Crustacea: Branchiopoda) as intermediate host of avian cestodes in Andean hypersaline lagoons from Salar de Atacama, Chile. Parasitol. Res. 2020, 119, 3377-3390. [CrossRef]

11. Jarecka, L. Development of Hymenolepis arctowskii Jarecka et Ostas, 1984 (Cestoda, Hymenolepididae) in the intermediate host Branchinecta gaini Daday (Branchiopoda) of the Antarctic. Acta Parasitol. Pol. 1984, 29, 337-342.

12. Bondarenko, S.; Kontrimavichus, V. Life-cycles of cestodes of the genus Branchiopodataenia Bondarenko \& Kontrimavichus, 2004 (Cestoda: Hymenolepididae) from gulls in Chukotka. Syst. Parasitol. 2004, 57, 191-199. [PubMed]

13. Caira, J.N.; Jensen, K.; Georgiev, B.B.; Kuchta, R.; Littlewood, D.T.J.; Mariaux, J.; Scholz, T.; Tkach, V.; Waeschenbach, A. An overview of tapeworms from vertebrate bowels of the earth. In Planetary Biodiversity Inventory (2008-2017): Tapeworms from Vertebrate Bowels of the Earth; Caira, J.N., Jensen, K., Eds.; Natural History Museum, University of Kansas: Lawrence, KS, USA, 2017; Volume 25, pp. 1-20.

14. Mariaux, J.; Tkach, V.V.; Vasileva, G.P.; Waeschenbach, A.; Beveridge, I.; Dimitrova, Y.D.; Haukisalmi, V.; Greiman, S.E.; Littlewood, D.T.J.; Makarikov, A.A.; et al. Cyclophyllidea van Beneden in Braun, 1900. In Planetary Biodiversity Inventory (2008-2017): Tapeworms from Vertebrate Bowels of the Earth; Caira, J.N., Jensen, K., Eds.; Natural History Museum, University of Kansas: Lawrence, KS, USA, 2017; Volume 25, pp. 77-148.

15. Redón, S.; Vasileva, G.P.; Georgiev, B.B.; Gajardo, G. First report of cestode infection in the crustacean Artemia persimilis from Southern Chilean Patagonia and its relation with the Neotropical aquatic birds. PeerJ 2019, 7, e7395. [CrossRef] [PubMed]

16. Guagliardo, S.E.; Graff, M.E.; Gigola, G.; Tanzola, R.D. Biological aspects of the life history of Confluaria podicipina (Cestoda, Hymenolepididae) from a hypersaline pampasic lagoon. Pan-Am. J. Aquat. Sci. 2020, 15, 54-63.

17. Poulin, R. Parasite biodiversity revisited: Frontiers and constraints. Int. J. Parasitol. 2014, 44, 581-589. [CrossRef]

18. Sánchez, M.I.; Nikolov, P.N.; Georgieva, D.D.; Georgiev, B.B.; Vasileva, G.P.; Pankov, P.; Paracuellos, M.; Lafferty, K.D.; Green, A.J. High prevalence of cestodes in Artemia spp. throughout the annual cycle: Relationship with abundance of avian final hosts. Parasitol. Res. 2013, 112, 1913-1923. [CrossRef]

19. Redón, S.; Amat, F.; Sánchez, M.I.; Green, A.J. Comparing cestode infections and their consequences for host fitness in two sexual branchiopods: Alien Artemia franciscana and native A. salina from syntopic-populations. Peer] 2015, 3, e1073. [CrossRef]

20. Redón, S.; Green, A.J.; Georgiev, B.B.; Vasileva, G.P.; Amat, F. Influence of developmental stage and sex on infection of the American brine shrimp Artemia franciscana Kellogg, 1906 by avian cestodes in Ebro Delta salterns, Spain. Aquat. Invasions 2015, 10, 415-423. [CrossRef]

21. Gajardo, G.; Redón, S. Hypersaline Lagoons from Chile, the Southern Edge of the World. In Lagoon Environments around the World-A Scientific Perspective; Manning, A.J., Ed.; IntechOpen: London, UK, 2019. [CrossRef]

22. Gajardo, G.; Redón, S. Andean hypersaline lakes in the Atacama Desert, northern Chile: Between lithium exploitation and unique biodiversity conservation. Conserv. Sci. Pract. 2019, 1, e94. [CrossRef]

23. Gajardo, G.; Colihueque, N.; Parraguez, M.; Sorgeloos, P. International study on Artemia LVIII. Morphologic differentiation and reproductive isolation of Artemia populations from South America. Int. J. Salt Lake Res. 1998, 7, 133-151. [CrossRef]

24. Gajardo, G.; Crespo, J.; Triantafyllidis, A.; Tzika, A.; Baxevanis, A.D.; Kappas, I.; Abatzopoulos, T.J. Species identification of Chilean Artemia populations based on mitochondrial DNA RFLP analysis. J. Biogeogr. 2004, 31, 547-555. [CrossRef] 
25. Amat, F.; Cohen, R.G.; Hontoria, F.; Navarro, J.C. Further evidence and characterization of Artemia franciscana populations in Argentina. J. Biogeogr. 2004, 31, 1-15. [CrossRef]

26. De los Ríos, P. Review of the biogeography of Artemia Leach, 1819 (Crustacea: Anostraca) in Chile. Int. J. Artemia Biol. 2013, 3, 64-67.

27. Yasuhara, M.; Hunt, G.; Dowsett, H.J.; Robinson, M.M.; Stoll, D.K. Latitudinal species diversity gradient of marine zooplankton for the last three million years. Ecol. Lett. 2012, 15, 1174-1179. [CrossRef]

28. Sebastián-González, E.; Green, A.J. Habitat use by waterbirds in relation to pond size, water depth, and isolation: Lessons from a restoration in southern Spain. Restor. Ecol. 2014, 22, 311-318. [CrossRef]

29. Caziani, S.M.; Derlindati, E.J.; Tálamo, A.; Sureda, A.L.; Trucco, C.E.; Nicolossi, G. Waterbird richness in altiplano wetlands of northwestern Argentina. Waterbirds 2001, 24, 103-117. [CrossRef]

30. Browne, R.A.; Sallee, S.E.; Grosch, D.S.; Segreti, W.O.; Purser, S.M. Partitioning genetic and environmental components of reproduction and lifespan in Artemia. Ecology 1984, 65, 949-960. [CrossRef]

31. Marazuela, M.A.; Vazquez-Sune, E.; Ayora, C.; Garcia-Gil, A.; Palma, T. Hydrodynamics of salt flat basins: The Salar de Atacama example. Sci. Total Environ. 2019, 651, 668-683. [CrossRef]

32. Caziani, S.M.; Olivio, O.R.; Ramirez, E.R.; Romano, M.; Derlindati, E.J.; Tálamo, A.; Ricalde, D.; Quiroga, C.; Contreras, J.P.; Valqui, M.; et al. Seasonal distribution, abundance, and nesting of Puna, Andean, and Chilean Flamingos. Condor 2007, 109, 276-287. [CrossRef]

33. Derlindati, E.J.; Romano, M.C.; Cruz, N.N.; Barison, C.; Arengo, F.; Barberis, I.M. Seasonal activity patterns and abundance of Andean flamingo (Phoenicoparrus andinus) at two contrasting wetlands in Argentina. Ornitol. Neotrop. 2014, 25, 317-331.

34. Vilina, Y.A.; Cofre, H.L.; Silva-Garcia, C.; Garcia, M.D.; Perez-Friedenthal, C. Effects of El Niño on abundance and breeding of Black-Necked Swans on El Yali wetland in Chile. Waterbirds 2002, 25, 123-127.

35. Fuentes-González, N.; Gajardo, G. A Glimpse to Laguna de Los Cisnes, a field laboratory and Natural Monument in the Chilean Patagonia. Lat. Am. J. Aquat. Res. 2017, 45, 491-495. [CrossRef]

36. Georgiev, B.B.; Sánchez, M.I.; Green, A.J.; Nikolov, P.N.; Vasileva, G.P.; Mavrodieva, R.S. Cestodes from Artemia parthenogenetica (Crustacea, Branchiopoda) in the Odiel Marshes, Spain: A systematic survey of cysticercoids. Acta Parasitol. 2005, 50, 105-117.

37. Redón, S.; Berthelemy, N.J.; Mutafchiev, Y.; Amat, F.; Georgiev, B.B.; Vasileva, G.P. Helminth parasites of Artemia franciscana (Crustacea: Branchiopoda) in the Great Salt Lake, Utah: First data from the native range of this invader of European wetlands. Folia Parasitol. 2015, 62, 030. [CrossRef]

38. Bush, A.O.; Lafferty, K.D.; Lotz, J.M.; Shostak, A.W. Parasitology meets ecology on its own terms: Margolis et al. revisited. J. Parasitol. 1997, 83, 575-583. [CrossRef]

39. Geobiota. Cambios y Mejoras en la Operación Minera del Salar de Atacama. Región Antofagasta. Informe de Seguimiento Ambiental (GEOB.SQM611). 2021. Available online: https:/ / snifa.sma.gob.cl/ (accessed on 5 June 2021).

40. eBird. eBird Basic Dataset; Cornell Lab of Ornithology: Ithaca, NY, USA, 2021.

41. Poulin, R.; Mouritsen, K.N. Large-scale determinants of trematode infections in intertidal gastropods. Mar. Ecol. Prog. Ser. 2003, 254, 187-198. [CrossRef]

42. Thieltges, D.W.; Ferguson, M.A.D.; Jones, C.S.; Noble, L.R.; Poulin, R. Biogeographical patterns of marine larval trematode parasites in two intermediate snail hosts in Europe. J. Biogeogr. 2009, 36, 1493-1501. [CrossRef]

43. Andrade, B.; Grau, S. La Laguna de Cáhuil, Un Ejemplo de Estuario Estacional En Chile Central. Rev. Geogr. Norte Gd. 2005, 33, 59-72.

44. Georgiev, B.B.; Angelov, A.; Vasileva, G.P.; Sánchez, M.I.; Hortas, F.; Mutafchiev, Y.; Pankov, P.; Green, A.J. Larval helminths in the invasive American brine shrimp Artemia franciscana throughout its annual cycle. Acta Parasitol. 2014, 59, 380-389. [CrossRef]

45. Boyle, T.P.; Caziani, S.M.; Waltermire, R.G. Landsat TM inventory and assessment of waterbird habitat in the southern altiplano of South America. Wetl. Ecol. Manag. 2004, 12, 563-573. [CrossRef]

46. Gutiérrez, J.S.; Soriano-Redondo, A. Wilson's Phalaropes can double their feeding rate by associating with Chilean flamingos. Ardea 2018, 106, 131-139. [CrossRef]

47. Hurlbert, S.H.; López, M.; Keith, J.O. Wilson's phalarope in the Central Andes and its interaction with the Chilean flamingo. Rev. Chil. Hist. Nat. 1984, 57, 47-57.

48. Garay, G.L.; Johnson, W.E.; Franklin, W.L. Relative abundance of aquatic birds and their use of wetlands in the Patagonia of southern Chile. Rev. Chil. Hist. Nat. 1991, 64, 127-137.

49. Garay, G.; Guineo, O.; Mutschke, E.; Ríos, C. Tamaño, estructura y distribución estacional de poblaciones de aves acuáticas en el Fiordo Última Esperanza y Canal Señoret, Región de Magallanes. An. Inst. Patagon. 2008, 36, 33-43. [CrossRef]

50. Gibbons, J.; Vilina, Y.A.; Cárcamo, J. Distribución y abundancia de Cisne Coscoroba (Coscoroba coscoroba), Cisne de Cuello Negro (Cygnus melancoryphus) y del Flamenco Chileno (Phoenicopterus chilensis) en la Región de Magallanes. An. Inst. Patagon. 2007, 35, 53-58.

51. Ramírez, I. Catastro de Fauna Monumento Natural Laguna de Los Cisnes; Departamento de Áreas Protegidas y Medio Ambiente, Ministerio de Agricultura: Santiago, Chile, 2009; 24p.

52. Tobar, C.; Rau, J.R.; Iriarte, A.; Villalobos, R.; Lagos, N.; Cursach, J.; Díaz, C.; Fuentes, N.; Gantz, A. Composition, diversity and size of diatoms consumed by the Andean Flamingo (Phoenicoparrus andinus) in salar de Punta Negra, Antofagasta Region, northern Chile. Ornitol. Neotrop. 2012, 23, 243-250. 
53. Polla, W.M.; Di Pasquale, V.; Rasuk, M.C.; Barberis, I.; Romano, M.; Manzo, R.A.; Paggi, J.C.; Farias, M.E.; Contreras, M.; Devercelli, M. Diet and feeding selectivity of the Andean Flamingo Phoenicoparrus andinus and Chilean Flamingo Phoenicopterus chilensis in lowland wintering areas. Wildfowl 2018, 68, 3-29.

54. Medina, G.R.; Goenaga, J.; Hontoria, F.; Cohen, G.; Amat, F. Effects of temperature and salinity on prereproductive life span and reproductive traits of two species of Artemia (Branchiopoda, Anostraca) from Argentina: Artemia franciscana and A. persimilis. Hydrobiologia 2007, 579, 41-53. [CrossRef]

55. Van Stappen, G. Zoogeography. In Artemia: Basic and Applied Biology; Springer: Dordrecht, The Netherlands, 2002; pp. 171-224.

56. Gajardo, G.; Beardmore, J.A. The brine shrimp Artemia: Adapted to critical life conditions. Front. Physiol. 2012, 3, 1-8. [CrossRef]

57. Vignatti, A.M.; Cabrera, G.C.; Pilati, A.; Echaniz, S.A. Biology of Artemia persimilis Piccinelli and Prosdocimi, 1968 (Crustacea: Anostraca) at the highest salinities reported for the species under natural conditions. Int. J. Artemia Biol. 2014, 4, 38-43.

58. De los Ríos-Escalante, P.; Gajardo, G. Potential heterogeneity in crustacean zooplankton assemblages in southern Chilean saline lakes. Braz. J. Biol. 2010, 70, 1031-1032. [CrossRef]

59. Shadrin, N.; Yakovenko, V.; Anufriieva, E. Suppression of Artemia spp. (Crustacea, Anostraca) populations by predators in the Crimean hypersaline lakes: A review of the evidence. Int. Rev. Hydrobiol. 2019, 104, 5-13. [CrossRef]

60. Bucher, E.H.; Curto, E. Influence of long-term climatic changes on breeding of the Chilean flamingo in Mar Chiquita, Córdoba, Argentina. Hydrobiologia 2012, 697, 127-137. [CrossRef]

61. Maksimova, A.P. Morphology and life cycle on the cestode Confluaria podicipina (Cestoda: Hymenolepididae). Parazitologiya 1981, 15, 325-331. (In Russian)

62. Redón, S.; Amat, F.; Hontoria, F.; Vasileva, G.P.; Nikolov, P.N.; Georgiev, B.B. Participation of metanauplii and juvenile individuals of Artemia parthenogenetica (Branchiopoda) in the circulation of avian cestodes. Parasitol. Res. 2011, 108, 905-912. [CrossRef]

63. Amarouyache, M.; Derbal, F.; Kara, M.H. The parasitism of Flamingolepis liguloides (Gervais, 1847) (Cestoda, Hymenolepididae) in Artemia salina (Crustacea, Branchiopoda) in two saline lakes in Algeria. Acta Parasitol. 2009, 54, 330-334. [CrossRef]

64. Lin, Q.; Xu, L.; Hou, J.; Liu, Z.; Jeppesen, E.; Han, B.P. Responses of trophic structure and zooplankton community to salinity and temperature in Tibetan lakes: Implication for the effect of climate warming. Water Res. 2017, 124, 618-629. [CrossRef] [PubMed]

65. Pavón-Jordán, D.; Clausen, P.; Dagys, M.; Devos, K.; Encarnacao, V.; Fox, A.D.; Frost, T.; Gaudard, C.; Hornman, M.; Keller, V.; et al. Habitat- and species-mediated short- and long-term distributional changes in waterbird abundance linked to variation in European winter weather. Divers. Distrib. 2019, 25, 225-239. [CrossRef] 